\title{
Metal-free Catalytic Hydrogenolysis of Silyl Triflates and Halides into Hydrosilanes
}

\author{
Gabriel Durin, Albane Fontaine, Jean-Claude Berthet, Emmanuel Nicolas, Pierre \\ Thuéry and Thibault Cantat* \\ Université Paris-Saclay, CEA, CNRS, NIMBE, 91191 Gif-sur-Yvette, France. E-mail: \\ thibault.cantat@cea.fr
}

\begin{abstract}
The metal-free catalytic hydrogenolysis of silyl triflates and halides (I, Br) to hydrosilanes is unlocked by using arylborane Lewis acids as catalysts. In the presence of a nitrogen base, the catalyst acts as a Frustrated Lewis Pair (FLP) able to split $\mathrm{H}_{2}$ and generate a boron hydride intermediate prone to reduce (pseudo)halosilanes. This metal-free organocatalytic system is competitive with metal-based catalysts and enables the formation of a variety of hydrosilanes at r.t. in high yields ( $>85 \%)$ under a low pressure of $\mathrm{H}_{2}(\leq 10 \mathrm{bar})$.
\end{abstract}

\section{Introduction}

Hydrosilanes are useful compounds for the production of a variety of organosilicon compounds through hydrosilylation of alkenes or dehydrocoupling reactions. ${ }^{[1]}$ They also promote, in mild conditions, the reduction of functional groups such as esters ${ }^{[2]}$ or amides ${ }^{[3]}$ with high selectivity. In comparison with apolar dihydrogen, the more reductant couple $\mathrm{E}^{0}\left(\mathrm{Si}(\mathrm{OEt})_{4(\mathrm{l})} / \mathrm{SiH}_{4(\mathrm{~g}}(-0.51 \mathrm{~V}\right.$ vs. NHE) and the polarized and weaker $\mathrm{Si}-\mathrm{H}$ bond $\left(\mathrm{BDE}_{\mathrm{Si}-\mathrm{H}}=95 \mathrm{kcal}_{\mathrm{mol}}{ }^{-1}<\right.$ $\mathrm{BDE}_{\mathrm{H}-\mathrm{H}}=104 \mathrm{kcal} \mathrm{mol}^{-1}$ ) offer some thermodynamic and kinetic advantages ${ }^{[4]}$ relevant for the reduction of oxygenated chemical feedstocks that will replace oil in the long run (lignin, plastics and $\left.\mathrm{CO}_{2}\right){ }^{[5]}$ Because classical routes for the production of hydrosilanes are energy demanding, ${ }^{[1 \mathrm{~b}, 6]}$ alternative catalytic syntheses that would transform $\mathrm{Si}-\mathrm{X}(\mathrm{X}=$ halides, alkoxides) precursors into $\mathrm{Si}-\mathrm{H}$ groups are appealing. This endeavor has motivated the recent elaboration of the first catalytic hydrogenolysis routes to hydrosilanes: in the presence of a suitable base, able to facilitate the thermodynamics of the reaction, $\mathrm{Si}-\mathrm{X}$ bonds (X $=\mathrm{OTf}, \mathrm{I}, \mathrm{Br}$, $\mathrm{Cl}$ ) in halosilanes were successfully reduced to $\mathrm{Si}-\mathrm{H}$ bonds. Yet, the catalysts reported so far by the groups of Shimada, Schneider and Cantat, ${ }^{[7]}$ all use catalytic systems based on molecular complexes of noble metals (Ir, Ru) (Scheme 1, top). To improve the sustainability of this reaction and gain fundamental insights into the generation of hydrosilanes, we have sought to unlock the first metal-free catalytic reduction $\mathrm{Si}-\mathrm{X}$ into $\mathrm{Si}-\mathrm{H}$ bonds under $\mathrm{H}_{2}$. Using boranes as catalysts, hydrosilanes $\left(\mathrm{Me}_{3} \mathrm{SiH}, \mathrm{Et}_{3} \mathrm{SiH}, \mathrm{Ph}_{3} \mathrm{SiH}\right.$ and $\left.{ }^{i} \mathrm{Pr}_{2} \mathrm{SiH}_{2}\right)$ were generated in yields up to $91 \%$, in the presence of an amine base. 


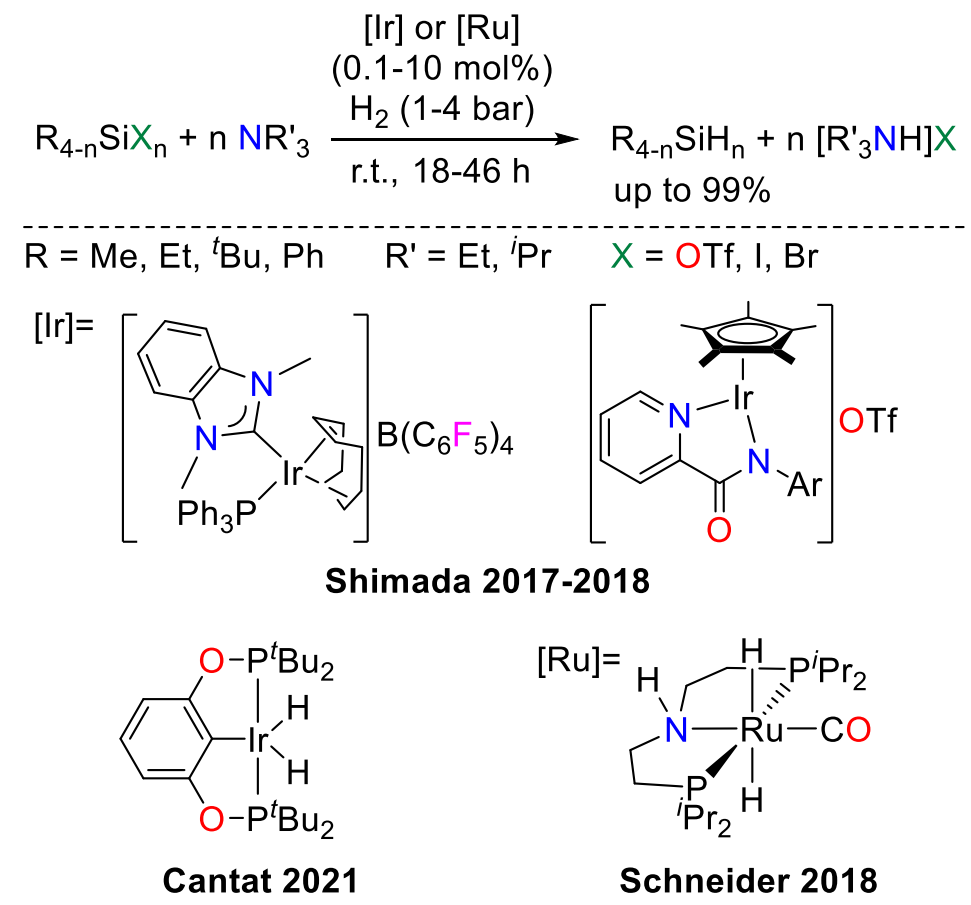

This work:

Scheme 1. Examples of catalytic routes that convert silyl halides and triflates into hydrosilanes with $\mathrm{H}_{2}$ as hydride source.

Mechanistic investigations derived from the iridium and ruthenium catalyzed hydrogenolysis of $\mathrm{Si}-\mathrm{X}$ bonds have shown that the generation of a metal hydride from $\mathrm{H}_{2}$ is key to yield a hydrosilane by hydride transfer to the silicon atom. ${ }^{[7 \mathrm{c}-\mathrm{e}]}$ To perform this deed without a metal, we have sought to use borohydrides as hydrogen transfer reagents. Indeed, borohydrides are known to convert halosilanes into hydrosilanes, as reported by the groups of Klejnot or Nakazawa for instance, who highlighted the stoichiometric reduction of chlorosilanes into hydrosilanes with lithium or sodium borohydride. ${ }^{[8]}$ Moreover, borohydride species can be generated from $\mathrm{H}_{2}$ using Frustrated Lewis Pairs (FLP) chemistry as demonstrated by Stephan and others if an appropriate Lewis base is present. ${ }^{[9]}$ The catalytic hydrogenation of organic functionalities using FLPs has been reported for alkynes, ${ }^{[10]}$ alkenes, ${ }^{[11]}$ ketones, ${ }^{[12]}$ silyl enol ethers, ${ }^{[13]}$ anilines, ${ }^{[14]}$ imines, ${ }^{[15]}$ enamines, ${ }^{[16]}$ amides, ${ }^{[17]}$ aza-Morita-Baylis-Hillman adducts, ${ }^{[18]}$ and esters. ${ }^{[19]}$ In the case of silyl halides and pseudohalides, a nitrogen base is necessary to be present in stoichiometric amount since the reaction is otherwise endergonic. ${ }^{[7 \mathrm{c}-}$

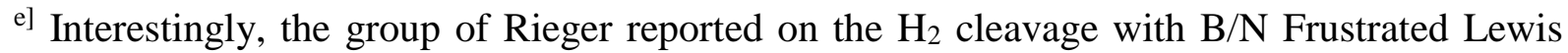
Pairs (amines and perfluorinated triarylboranes). ${ }^{[20]}$ The group of O'Hare later demonstrated that the generated borohydride is efficient in the reduction of $\mathrm{CO}_{2}{ }^{[21]}$ This result prompted us to consider aryl boranes as catalysts for the hydrogenolysis of $\mathrm{Si}-\mathrm{X}$ into $\mathrm{Si}-\mathrm{H}$ bonds, together with stoichiometric amount of nitrogen bases, effectively forming an FLP system in solution. 
Using $10 \mathrm{~mol} \% \mathrm{~B}\left(\mathrm{C}_{6} \mathrm{~F}_{5}\right)_{3}$ and 1.1 equiv. TMP (2,2,6,6-tetramethylpiperidine), only traces of $\mathrm{Me}_{3} \mathrm{SiH}$ were obtained from $\mathrm{Me}_{3} \mathrm{SiOTf}$ under 10 bar of $\mathrm{H}_{2}$ at r.t. in $\mathrm{CD}_{2} \mathrm{Cl}_{2}$ (Table 1, entry 1). The reactivity of a variety of boranes, i.e. $\mathrm{BPh}_{3}, \mathrm{~B}\left(4-\mathrm{F}-\mathrm{C}_{6} \mathrm{H}_{4}\right)_{3}, \mathrm{~B}\left(2-\mathrm{F}-\mathrm{C}_{6} \mathrm{H}_{4}\right)_{3}, \mathrm{~B}\left(2,6-\mathrm{F}_{2}-\mathrm{C}_{6} \mathrm{H}_{3}\right)_{3}$ and $\mathrm{HB}\left(\mathrm{C}_{6} \mathrm{~F}_{5}\right)_{2}$ with distinct Lewis acidities ${ }^{[22]}$ was thus evaluated. These performances slightly increased with Piers borane ${ }^{[23]} \mathrm{HB}\left(\mathrm{C}_{6} \mathrm{~F}_{5}\right)_{2}$ which afforded $21 \%$ NMR yield in $\mathrm{Me}_{3} \mathrm{SiH}$ (Table 1, entry 2). In contrast, $\mathrm{B}\left(2,6-\mathrm{F}_{2}-\mathrm{C}_{6} \mathrm{H}_{3}\right)_{3}$ and $\mathrm{B}\left(2-\mathrm{F}-\mathrm{C}_{6} \mathrm{H}_{4}\right)_{3}$ proved quite reactive affording $\mathrm{Me}_{3} \mathrm{SiH}$ in excellent yields (88 and $85 \%$ respectively) (Table 1, entries 3 and 4). Compounds $\mathrm{BPh}_{3}$ and its para- $\mathrm{F}$ analogue displayed a low efficiency with a poor $\mathrm{Me}_{3} \mathrm{SiH}$ yield of $4 \%$ (Table 1, entries 5 and 6). With the most reactive FLP, i.e. the TMP/ B $\left(2,6-\mathrm{F}_{2}-\mathrm{C}_{6} \mathrm{H}_{3}\right)_{3}$ couple (Table 1, entry 4), a drop in the $\mathrm{Me}_{3} \mathrm{SiH}$ yields was observed either by decreasing the $\mathrm{H}_{2}$ pressure from 10 to 5 bar (88 to $66 \%$ yield, see ESI Section 2.1.6) or the borane catalyst loading from 10 to $5 \mathrm{~mol} \%$ (67\% yield, see ESI Section 2.1.7). The results represent the first examples of a metal-free hydrogenolysis of a (pseudo)halosilanes.

Table 1. Screening of borane catalysts for the hydrogenolysis of $\mathrm{Me}_{3} \mathrm{SiOTf}^{[\mathrm{a}]}$

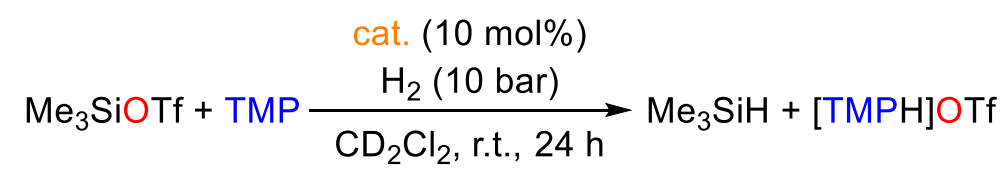

\begin{tabular}{lllll}
\hline Entry & Borane & $\begin{array}{l}\text { Computed hydricity } \\
{\left[\mathrm{kcal}^{[24]} \mathrm{mol}^{-1}\right]}\end{array}$ & $\mathrm{Conv}^{[\mathrm{b}]}[\%]$ & ${\text { Yield (Select. })^{[\mathrm{b}]}[\%]}^{[\%}$ \\
\hline 1 & $\mathrm{~B}\left(\mathrm{C}_{6} \mathrm{~F}_{5}\right)_{3}$ & 65 & $<1$ & traces \\
2 & $\mathrm{HB}\left(\mathrm{C}_{6} \mathrm{~F}_{5}\right)_{2}$ & 61 & 21 & $21(99)$ \\
3 & $\mathrm{~B}\left(2,6-\mathrm{F}_{2}-\right.$ & 51 & 95 & $88(92)$ \\
4 & $\left.\mathrm{C}_{6} \mathrm{H}_{3}\right)_{3}$ & & 96 & $85(88)$ \\
5 & $\mathrm{~B}\left(2-\mathrm{F}_{-}-\mathrm{C}_{6} \mathrm{H}_{4}\right)_{3}$ & $48^{[\mathrm{c}]}$ & 4 & $4(99)$ \\
6 & $\mathrm{~B}\left(4-\mathrm{F}_{-} \mathrm{C}_{6} \mathrm{H}_{4}\right)_{3}$ & 37 & 5 & $4(80)$
\end{tabular}

[a] General conditions: $\mathrm{Me}_{3} \operatorname{SiOTf}(0.1 \mathrm{mmol})$, TMP $(0.11 \mathrm{mmol})$, borane $(10 \mu \mathrm{mol}), \mathrm{CD}_{2} \mathrm{Cl}_{2}$ (0.5 mL), $\mathrm{H}_{2}(10 \mathrm{bar}), 25^{\circ} \mathrm{C} .{ }^{[b]}$ Conversions, selectivities, and yields were determined through integration of the $\mathrm{Me}_{3} \mathrm{Si}-$ signals by ${ }^{1} \mathrm{H}$ NMR versus an internal standard $(1,3,5-$ trimethylbenzene). ${ }^{[\mathrm{c}]}$ This value was calculated for this work.

The NMR yields in $\mathrm{Me}_{3} \mathrm{SiH}$ were plotted against the hydridicity of the different borane catalysts, that corresponds to the energy required to release a hydride ion $\mathrm{H}^{-}$from a putative borohydride $\left[\mathrm{R}_{3} \mathrm{BH}\right]^{-}$(Figure 1). B-H hydricity values can be obtained from the hydricity scale computed by Heiden et al. for main group hydrides; ${ }^{[24]}$ they quantify the stability of the borohydrides and help appreciating their reducing power. Figure 1 highlights a volcano-type distribution similar to those resulting from the Sabatier principle for heterogeneous catalysts. ${ }^{\text {[25] }}$ It reveals that borohydrides having the lowest hydricities such as $\left[\mathrm{HBPh}_{3}\right]^{-}\left(36 \mathrm{kcal}^{\mathrm{mol}}{ }^{-1}\right)$ or

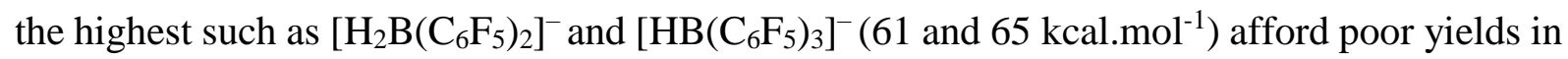
hydrosilane. This plot likely reveals that a balance must be achieved for an efficient catalytic turnover, where the borane is acidic enough to yield a borohydride from the activation of $\mathrm{H}_{2}$, yet able to transfer a hydride ligand to silicon in a subsequent step. 


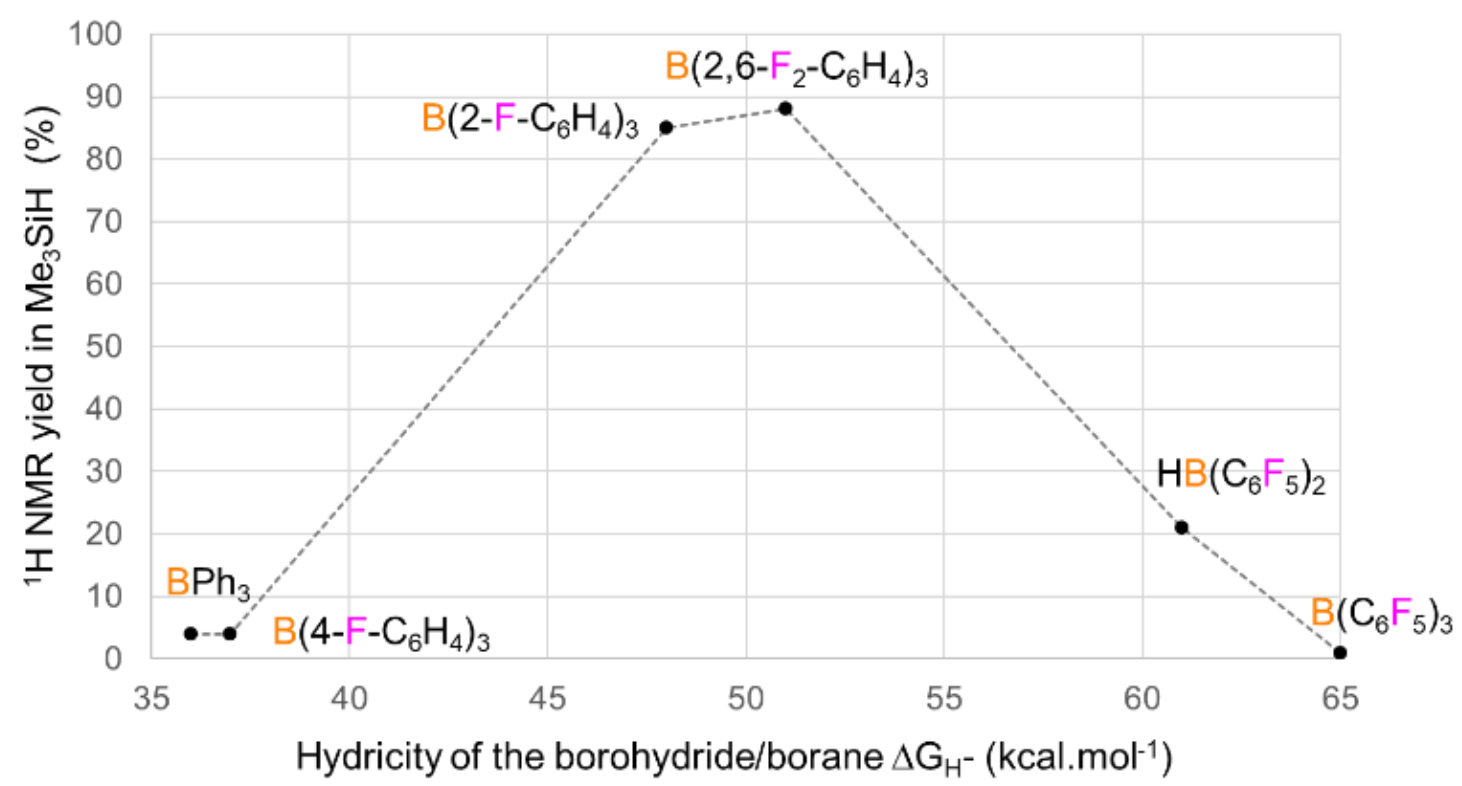

Figure 1. Volcano plot with NMR yield, obtained from Table 2, plotted against the hydricity ${ }^{[24]}$ of the different arylborane catalysts.

Table 2. Screening of bases for the hydrogenolysis of $\mathrm{Me}_{3} \mathrm{SiOTf}_{\text {in }} \mathrm{CD}_{2} \mathrm{Cl}_{2}$. ${ }^{[\mathrm{a}]}$

$$
\mathrm{Me}_{3} \mathrm{SiOTf}+\text { Base } \underset{\mathrm{C}}{\left.\stackrel{\mathrm{B}\left(2,6-\mathrm{F}_{2}-\mathrm{C}_{6} \mathrm{H}_{3}\right)_{3}(10 \mathrm{~mol} \%)}{\mathrm{CD}_{2} \mathrm{Cl}_{2}, \text { r.t., } 24 \mathrm{~h}} \mathrm{bar}\right)} \mathrm{Me} 3 \mathrm{SiH}+[\mathrm{HBase}] \mathrm{OTf}
$$

\begin{tabular}{lllll}
\hline Entry & Base & pKa $^{[\mathrm{b}]}$ & Conv. $^{[\mathrm{c}]}[\%]$ & Yield (Select. $^{[\mathrm{c}]}[\%]$ \\
\hline 1 & 2,6 -lutidine & 14.1 & 22 & $15(68)$ \\
2 & Pr2NEt $_{2}$ (S) & 18.1 & 48 & $18(38)$ \\
3 & NEt3 & 18.8 & 82 & $55(67)$ \\
4 & TMP & 18.6 & 95 & $88(92)$ \\
5 & PMP & 18.2 & 39 & $24(62)$
\end{tabular}

[a] General conditions: $\mathrm{Me}_{3} \operatorname{SiOTf}(0.1 \mathrm{mmol})$, base $(0.11 \mathrm{mmol}), \mathrm{B}\left(2,6-\mathrm{F}_{2}-\mathrm{C}_{6} \mathrm{H}_{3}\right)_{3}(10 \mu \mathrm{mol})$, $\mathrm{CD}_{2} \mathrm{Cl}_{2}(0.5 \mathrm{~mL}), \mathrm{H}_{2}(10 \mathrm{bar}), 25{ }^{\circ} \mathrm{C}{ }^{[\mathrm{b}]} \mathrm{pKa}$ in MeCN. ${ }^{[26]}{ }^{[\mathrm{c}]}$ Conversions, selectivities, and yields were determined by ${ }^{1} \mathrm{H}$ NMR spectroscopy, through integration of the $\mathrm{Me}_{3} \mathrm{Si}$ signals versus an internal standard (1,3,5-trimethylbenzene).

The role of the nitrogen base was then evaluated by considering a variety of classical and sterically congested amines, ${ }^{[21,27]}$ e.g. 2,6-lutidine, trialkylamines $\mathrm{NEt}_{3}$ and ${ }^{i} \mathrm{Pr}_{2} \mathrm{NEt}$, and piperidines (TMP and $\mathrm{PMP}=1,2,2,6,6$-pentamethylpiperidine) in the conditions depicted in Table 2. With 2,6-lutidine, the reaction led after $24 \mathrm{~h}$ at room temperature to the formation of $\mathrm{Me}_{3} \mathrm{SiH}$ in $15 \%$ yield (Table 2, entry 1). Replacing 2,6-lutidine with trialkylamines $\mathrm{NEt}_{3}$ or ${ }^{i} \mathrm{Pr}_{2} \mathrm{NEt}$ increased the spectroscopic yield in $\mathrm{Me}_{3} \mathrm{SiH}$ (18 and $55 \%$, respectively) (Table 2, entries 2 and 3). This yield reached $88 \%$ with bulky piperidine TMP (Table 2, entry 4 or Table 1 , entry 3) but dropped to $24 \%$ with the N-methylated derivative of TMP $(1,2,2,6,6-$ pentamethylpiperidine, PMP), thus underlining a possible influence of the NH group (Table 2, entry 5). A plausible explanation for such a behavior might be the presence of hydrogen bonding $\mathrm{N}-\mathrm{H} \bullet \bullet \mathrm{F}$ interactions between the secondary amine and the fluorine atoms on the triarylborane, 
reminding of the adduct described by Bourissou et al. ${ }^{[28]}$ that pre-organize the FLP for a better activation of $\mathrm{H}_{2}$ and overall, a more favorable catalytic process. ${ }^{\text {[29] }}$

The most productive bases have a pKa greater than 18 , while 2,6-lutidine $(\mathrm{pKa}=14)$ afforded the lowest yield in $\mathrm{Me}_{3} \mathrm{SiH}$. Nonetheless, as noted previously with transition metal catalysts, ${ }^{[7 \mathrm{~d}]}$ the Brønsted basicity is not the sole parameter influencing the reactivity of the nitrogen base: $\mathrm{NEt}_{3}$ and ${ }^{i} \mathrm{Pr}_{2} \mathrm{NEt}$ are readily trapped by $\mathrm{Me}_{3} \mathrm{SiOTf}$ to form the silylated ammonium salts $\left[\mathrm{R}_{3} \mathrm{NSiMe}_{3}\right][\mathrm{Otf}]$, which has a decreased reactivity compared to the free silyl triflate. These silylated ammonium salts were, in contrast, not observed with the piperidines for which the hydrogenolysis proceeded in $\mathrm{CD}_{2} \mathrm{Cl}_{2}$ with gradual deposition of the insoluble [TMPH] [OTf] or partially soluble [PMPH][OTf] salts (Table 2, entries 4 and 5). When performed with stirring, the reaction proved to be faster in benzene than in dichloromethane, and $3 \mathrm{~h}$ instead of $24 \mathrm{~h}$ were required to reach the same yield in $\mathrm{Me}_{3} \mathrm{SiH}(91 \%)$, with $\mathrm{TMP} / \mathrm{B}\left(2,6-\mathrm{F}_{2}-\mathrm{C}_{6} \mathrm{H}_{3}\right)_{3}$ (ESI, Section 2.1.5).

The applicability of this catalytic route using these optimized conditions was evaluated with a series of silyl triflates and halides (Table 3). Similar to $\mathrm{Me}_{3} \mathrm{SiOTf}_{3} \mathrm{Et}_{3} \mathrm{SiOTf}$ is almost fully converted into $\mathrm{Et}_{3} \mathrm{SiH}(90 \%)$ with an excellent selectivity within $3 \mathrm{~h}$ (Table 3, entries 1 and 2). Formation of the bulky $\mathrm{Ph}_{3} \mathrm{SiH}$ is much slower and required $48 \mathrm{~h}$ to reach $88 \%$ yield from $\mathrm{Ph}_{3}$ SiOTf (Table 3, entry 3). The double hydrogenolysis of the bis triflate ${ }^{i} \operatorname{Pr}_{2} \mathrm{Si}(\mathrm{Otf})_{2}$ is twice as fast as the hydrogenolysis of $\mathrm{Ph}_{3} \mathrm{SiOTf}$ and provides ${ }^{i} \mathrm{Pr}_{2} \mathrm{SiH}_{2}$ in $86 \%$ yield (Table 3, entry 4). Attempts to synthesize ${ }^{i} \mathrm{Pr}_{2} \mathrm{SiH}(\mathrm{OTf})$ by using only 1.1 equivalent of TMP afforded ${ }^{i} \mathrm{Pr}_{2} \mathrm{SiH}_{2}$ as the major product (41\%) with low yields in the desired ${ }^{i} \operatorname{Pr}_{2} \operatorname{SiH}(\mathrm{OTf})(9 \%$ ) (Table 3, entry 5). Compared to $\mathrm{Me}_{3} \mathrm{SiOTf}$, the reduction of $\mathrm{Me}_{3} \mathrm{SiI}$ and $\mathrm{Me}_{3} \mathrm{SiBr}$ is slower requiring $7 \mathrm{~h}$ and $16 \mathrm{~h}$, respectively, to reach $88 \%$ and $71 \%$ yields in $\mathrm{Me}_{3} \mathrm{SiH}$ (Table 3, entries 6-7). Finally, only traces of hydrosilane could be detected in the hydrogenolysis of $\mathrm{Me}_{3} \mathrm{SiCl}$ (Table 3, entry 8). These findings are consistent with the trends obtained using organometallic catalysts for the hydrogenolysis of (pseudo)halosilanes, pointing to a more difficult cleavage of the $\mathrm{Si}-\mathrm{Cl}$ bond. ${ }^{[7 \mathrm{c}, 7 \mathrm{e}]}$

The hydrogenolysis of (pseudo)halosilanes is somewhat more efficient using the borane catalyst compared to the known Ir and Ru catalysts, which require prolonged reaction times and higher temperatures. For example, $\mathrm{Me}_{3} \mathrm{SiH}$ was obtained in $11 \%$ yield with an iridium amido catalyst from $\mathrm{Me}_{3} \mathrm{SiBr}$ and ${ }^{i} \mathrm{Pr}_{2} \mathrm{NEt}$, after $48 \mathrm{~h}$ at $60{ }^{\circ} \mathrm{C} .{ }^{[7 \mathrm{a}]}$ In the case of $\mathrm{Ru}$ (II) bearing a participative ligand, improved performances are reported: $\mathrm{Me}_{3} \mathrm{SiH}$ was obtained in $85 \%$ yield from $\mathrm{Me}_{3} \mathrm{SiOTf}$ after $18 \mathrm{~h}$ at r.t., with only $1 \mathrm{~mol} \%$ catalyst loading. These results are close to the $91 \%$ yield obtained after $3 \mathrm{~h}$ with $10 \mathrm{~mol} \%$ loading for the borane-catalyzed reaction (Table 3, entry 1$)$.

To gain insights into the mechanism of the reaction, stoichiometric experiments have been conducted (Scheme 2). In line with the findings of Paradies et al., ${ }^{[30]}\left[\mathrm{HB}\left(2,6-\mathrm{F}_{2}-\right.\right.$ $\left.\left.\mathrm{C}_{6} \mathrm{H}_{3}\right)_{3}\right][\mathrm{TMPH}]$ could be generated in near quantitative yield by reacting $\mathrm{B}\left(2,6-\mathrm{F}_{2}-\mathrm{C}_{6} \mathrm{H}_{3}\right)_{3}$ and 1.1 equiv. TMP, under 10 bar of $\mathrm{H}_{2}$, at r.t. in $\mathrm{C}_{6} \mathrm{D}_{6}$. Addition of $\mathrm{Me}_{3} \mathrm{SiOTf}$ to the latter solution yielded $\mathrm{Me}_{3} \mathrm{SiH}(93 \%)$ within 5 minutes at r.t., together with $\mathrm{B}\left(2,6-\mathrm{F}_{2}-\mathrm{C}_{6} \mathrm{H}_{3}\right)_{3}$ and a white deposit of [TMPH][OTf]. 
Table 3. Scope of the reaction. ${ }^{[a]}$

$$
\begin{aligned}
& \mathrm{B}\left(2,6-\mathrm{F}_{2}-\mathrm{C}_{6} \mathrm{H}_{3}\right)_{3}(10 \mathrm{~mol} \%)
\end{aligned}
$$

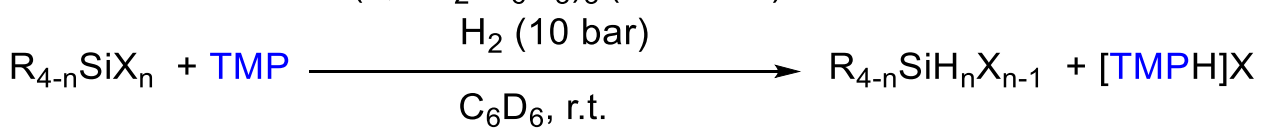

\begin{tabular}{|c|c|c|c|c|c|}
\hline Entry & $\begin{array}{l}\text { Reagent } \\
\text { R4-nSiXn }\end{array}$ & $\begin{array}{l}\text { Product } \\
\mathrm{R}_{4-\mathrm{nSiH}} \mathrm{X}_{\mathrm{n}-1}\end{array}$ & $\begin{array}{l}\text { Reaction } \\
\text { time }[\mathrm{h}]\end{array}$ & Conv. $[\mathrm{b}][\%]$ & $\begin{array}{l}\text { Yield } \\
\text { (Select. }^{[b]} \\
{[\%]} \\
\end{array}$ \\
\hline 1 & $\mathrm{Me}_{3} \mathrm{SiOTf}$ & $\mathrm{Me}_{3} \mathrm{SiH}$ & 3 & 96 & $91(95)$ \\
\hline 2 & $\mathrm{Et}_{3} \mathrm{SiOTf}$ & $\mathrm{Et}_{3} \mathrm{SiH}$ & 3 & 93 & $90(97)$ \\
\hline 3 & $\mathrm{Ph}_{3} \mathrm{SiOTf}$ & $\mathrm{Ph}_{3} \mathrm{SiH}$ & 48 & 89 & 88 (99) \\
\hline \multirow[t]{2}{*}{$4^{[c, d]}$} & $\left.{ }^{i P_{2} S i(O T f}\right)_{2}$ & $\mathrm{Pr}_{2} \mathrm{SiH}_{2}$ & 24 & 94 & $86(91)$ \\
\hline & & $\mathrm{Pr}_{2} \mathrm{SiH}_{2}$ & & & $41(68)$ \\
\hline \multirow[t]{2}{*}{$5^{[\mathrm{d}]}$} & ${ }^{\mathrm{P}} \mathrm{rr}_{2} \mathrm{Si}(\mathrm{OTf})_{2}$ & & 24 & 60 & \\
\hline & & 'Pr2SiHOTf & & & $9(15)$ \\
\hline 6 & MeзSil & $\mathrm{Me}_{3} \mathrm{SiH}$ & 7 & 89 & 88 (99) \\
\hline 7 & $\mathrm{Me}_{3} \mathrm{SiBr}$ & $\mathrm{Me}_{3} \mathrm{SiH}$ & 16 & 87 & $71(82)$ \\
\hline 8 & $\mathrm{Me} 3 \mathrm{SiCl}$ & $\mathrm{Me}_{3} \mathrm{SiH}$ & 48 & $<1$ & traces \\
\hline
\end{tabular}

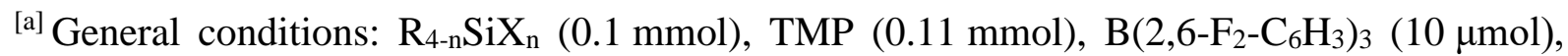
$\mathrm{C}_{6} \mathrm{D}_{6}(0.5 \mathrm{~mL}), \mathrm{H}_{2}(10 \mathrm{bar}), 25{ }^{\circ} \mathrm{C}{ }^{[\mathrm{b}]}$ Conversions, selectivities, and yields were determined by ${ }^{1} \mathrm{H}$ NMR spectroscopy, through integration of the $\mathrm{R}_{4-\mathrm{n}} \mathrm{Si}$ signals versus the internal standard 1,3,5-trimethylbenzene. ${ }^{[\mathrm{c}]} 0.22 \mathrm{mmol}$ of TMP was used. ${ }^{[\mathrm{d}]} \mathrm{In} \mathrm{CD}_{2} \mathrm{Cl}_{2}$.

$$
\begin{aligned}
& \mathrm{H}_{2} \text { splitting }
\end{aligned}
$$

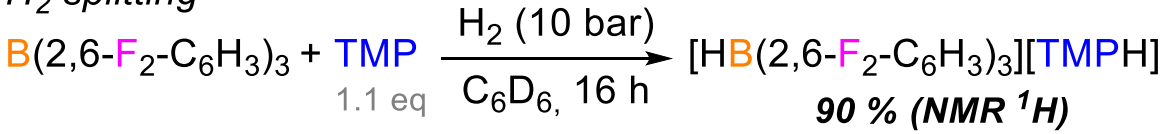

\section{Hydride transfer}

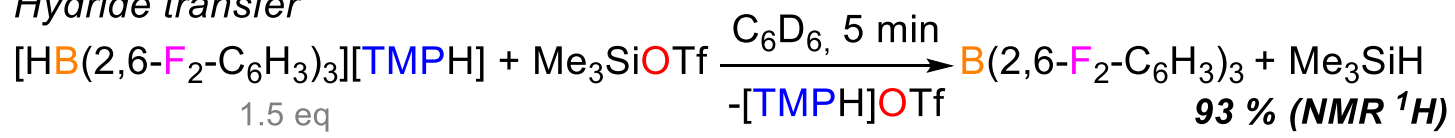

Scheme 2. Stoichiometric experiment for the $\mathrm{H}_{2}$ splitting by the FLP B(2,6- $\left.\mathrm{F}_{2}-\mathrm{C}_{6} \mathrm{H}_{3}\right)_{3} / \mathrm{TMP}$ and further hydride transfer into Me3SiOTf.

These two reactions suggest a mechanism in two steps depicted in Scheme 3, which is supported by DFT calculations at the M06-2X/6-311+G(d) level of theory (using the SMD model to account for the solvation effects due to benzene). The activation of $\mathrm{H}_{2}$ is exergonic $\left(\Delta \mathrm{G}=-1.3 \mathrm{kcal} . \mathrm{mol}^{-1}\right)$ and proceeds via transition state $\mathrm{TS}_{1}\left(\Delta \mathrm{G}^{\ddagger}=20.2 \mathrm{kcal}^{\circ} \mathrm{mol}^{-1}\right)$ to yield the ion pair $\left[\mathrm{HB}\left(2,6-\mathrm{F}_{2}-\mathrm{C}_{6} \mathrm{H}_{3}\right)_{3}\right][\mathrm{TMPH}]$. The latter transfers its hydride in a barrierless endergonic step $\left(\Delta \mathrm{G}=+1.3 \mathrm{kcal}^{\mathrm{mol}} \mathrm{m}^{-1}\right)$, affording $\mathrm{Me}_{3} \mathrm{SiH}$, free borane $\mathrm{B}\left(2,6-\mathrm{F}_{2}-\mathrm{C}_{6} \mathrm{H}_{3}\right)_{3}$, and the salt [TMPH][OTf] as by-product. Since boranes are strong oxophiles, the triflate salt is able to coordinate to the free borane, to form the off-cycle adduct $\left[(\mathrm{TfO}) \mathrm{B}\left(2,6-\mathrm{F}_{2}-\mathrm{C}_{6} \mathrm{H}_{3}\right)_{3}\right]^{-}$ $\left(\Delta \mathrm{G}=+0.6 \mathrm{kcal} \cdot \mathrm{mol}^{-1}\right)$. This equilibrium might in turn slow down the catalysis, due to quenching of the vacant site of the Lewis acid catalyst.

Overall, the rate determining step is the splitting of $\mathrm{H}_{2}$ with an energetic span of $20.2 \mathrm{kcal} . \mathrm{mol}^{-}$ ${ }^{1}\left(\mathrm{TS}_{1}\right)$ consistent with the catalytic experimental conditions $\left(10\right.$ bar $\mathrm{H}_{2}$, r.t., $3 \mathrm{~h}$ for full 
completion at $10 \mathrm{~mol} \%$ catalytic loading). A kinetic study based on the time-scale normalization method described by Burés ${ }^{[31]}$ was performed and revealed a partial order of 1 for the base and 0 for the silyl triflate (see ESI, section 2.3). Such values are in agreement with the DFT calculations and the experiments. A complex order (ca. 0.1) for the borane was also found which shows the detrimental influence of the interaction between $\mathrm{B}\left(2,6-\mathrm{F}_{2}-\mathrm{C}_{6} \mathrm{H}_{3}\right)_{3}$ and $\mathrm{TfO}^{-}$.

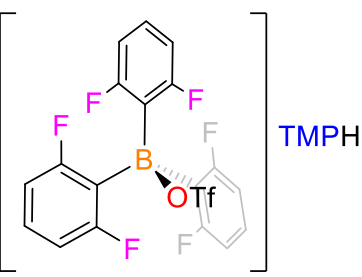

0.6

$\begin{array}{ll}\text { TS }_{2} \\ 6.2\end{array}+[$ TMPH]OTf $\|$-[TMPH]OTf

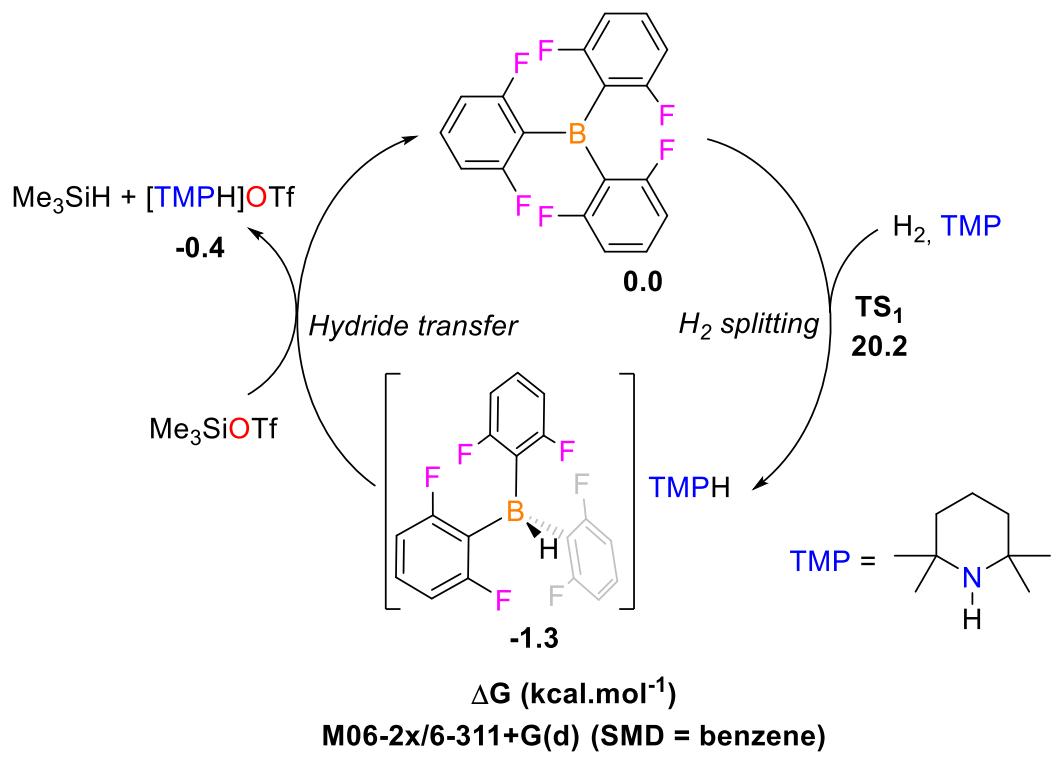

Scheme 3. Computed mechanism for the hydrogenolysis of $\mathrm{Me}_{3} \mathrm{SiOTf}$ with the FLP $\left(\mathrm{TMP} / \mathrm{B}\left(2,6-\mathrm{F}_{2}-\mathrm{C}_{6} \mathrm{H}_{3}\right)_{3}\right)(\mathrm{M} 06-2 \mathrm{X} / 6-311+\mathrm{G}(\mathrm{d})$ level of theory, solvent (benzene) effects are taken into account with SMD).

Capitalizing on this mechanistic knowledge, we next targeted the hydrogenolysis of chlorosilanes, an appealing yet challenging class of substrates ${ }^{[7]}$ Regardless of the nature of the base, $\mathrm{B}\left(2,6-\mathrm{F}_{2}-\mathrm{C}_{6} \mathrm{H}_{3}\right)_{3}$ proved unproductive in the conversion of $\mathrm{Me}_{3} \mathrm{SiCl}$ to $\mathrm{Me}_{3} \mathrm{SiH}$. Nonetheless, as $\mathrm{Me}_{3} \mathrm{SiCl}$ has a lower reactivity than $\mathrm{Me}_{3} \mathrm{SiOTf}$, we have considered a mildly acidic borane $\left(\mathrm{BPh}_{3}\right)$ in the presence of the strong phosphazene base BTPP (tert-butyliminotri(pyrrolidino)phosphorane) to split $\mathrm{H}_{2}$ and generate a highly reactive borohydride (hydridicity of $\left.36 \mathrm{kcal}^{\mathrm{mol}}{ }^{-1}\right)^{[24]}$ (Scheme 4). This particular reaction will be further studied and optimized.

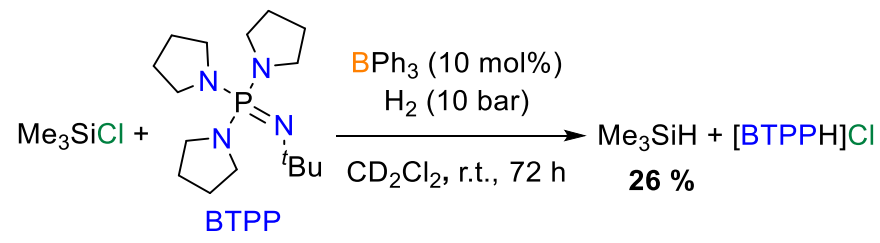

Scheme 4. Hydrogenolysis of $\mathrm{Me}_{3} \mathrm{SiCl}$ with the phosphazene $\mathrm{BTPP}$ and $\mathrm{BPh}_{3}$. 
In summary, we have developed an unprecedented transition metal free catalytic route for the hydrogenolysis of silyl triflates and halides (I, Br), using di- and triarylboranes as catalysts. A delicate balance of the Lewis acidity of the borane catalyst is essential for a good activity. In the presence of the base, the catalyst acts as a B/N FLP and the combination of $\mathrm{B}\left(2,6-\mathrm{F}_{2}-\mathrm{C}_{6} \mathrm{H}_{3}\right)_{3}$ and TMP proved the most efficient to afford hydrosilanes in high yields at room temperature and under a low pressure $\left(10 \mathrm{bar}_{\mathrm{H}}\right)$. Experimental reactions, kinetic data and theoretical calculations support a two steps mechanism with a rate-determining step being the heterolytic splitting of $\mathrm{H}_{2}$. This results paves the way for new catalytic systems for the sustainable synthesis of hydrosilanes, a necessary step towards a closed silicon cycle.

\section{Conflict of interest}

The authors declare no conflict of interest.

\section{Acknowledgements}

For financial support of this work, we acknowledge CEA, CNRS, the University Paris-Saclay, CINES (HPC Computing time on Occigen, grant no. A0100806494) and the European Research Council (ERC Consolidator Grant Agreement no. 818260). T.C. thanks the Fondation Louis D.-Institut de France for its major support.

Keywords: Hydrosilane synthesis $\bullet$ Metal-free $\bullet$ hydrogenolysis $\bullet$ Frustrated Lewis pair $\bullet \mathrm{H}_{2}$ activation $•$ Borohydrides

\section{References}

[1] a) B. Marciniec, in Hydrosilylation, Vol. 1 (Ed.: B. Marciniec), Springer Netherlands, Dordrecht, 2009, pp. 159-189; b) L. Rösch, P. John, R. Reitmeier, in Ullmann's Encyclopedia of Industrial Chemistry (Eds.: V. C. H. V. G. Wiley, K. Co), Wiley-VCH Verlag GmbH \& Co. KGaA, Weinheim, Germany, 2000, pp. 637-669.

[2] a) H. Li, L. C. Misal Castro, J. Zheng, T. Roisnel, V. Dorcet, J. B. Sortais, C. Darcel, Angew. Chem. Int. Ed. 2013, 52, 8045-8049; b) S. Hosokawa, M. Toya, A. Noda, M. Morita, T. Ogawa, Y. Motoyama, ChemistrySelect 2018, 3, 2958-2961.

[3] S. Das, D. Addis, S. Zhou, K. Junge, M. Beller, J. Am. Chem. Soc. 2010, 132, 17701771.

[4] C. Chauvier, T. Cantat, ACS Catal. 2017, 7, 2107-2115.

[5] a) E. Feghali, T. Cantat, ChemSusChem 2015, 8, 980-984; b) L. Monsigny, E. Feghali, J.-C. Berthet, T. Cantat, Green Chem. 2018, 20, 1981-1986; c) M. Rauch, Z. Strater, G. Parkin, J. Am. Chem. Soc. 2019, 141, 17754-17762.

[6] W. Kalchauer, B. Pachaly, in Handbook of Heterogeneous Catalysis, Wiley-VCH Verlag GmbH \& Co. KGaA, 2008, p. 2635_2647.

[7] a) D. Tsushima, M. Igarashi, K. Sato, S. Shimada, Chem. Lett. 2017, 46, 1532-1534; b) T. Beppu, K. Sakamoto, Y. Nakajima, K. Matsumoto, K. Sato, S. Shimada, J. Organomet. Chem. 2018, 869, 75-80; c) A. Gluer, J. I. Schweizer, U. S. Karaca, C. Wurtele, M. Diefenbach, M. C. Holthausen, S. Schneider, Inorg. Chem. 2018, 57, 13822-13828; d) G. Durin, J.-C. Berthet, E. Nicolas, P. Thuéry, T. Cantat, Organometallics 2021; e) G. Durin, J. C. Berthet, E. Nicolas, T. Cantat, ACS Catal. 2021, 11, 10855-10861. 
[8] a) O. J. Klejnot, Inorg. Chem. 1963, 2, 825-\&; b) M. Ito, M. Itazaki, T. Abe, H. Nakazawa, Chem. Lett. 2016, 45, 1434-1436.

[9] a) G. C. Welch, R. R. San Juan, J. D. Masuda, D. W. Stephan, Science 2006, 314, 11241126; b) D. W. Stephan, G. Erker, Angew. Chem. Int. Ed. 2010, 49, 46-76; c) J. Paradies, Eur. J. Org. Chem. 2019, 2019, 283-294; d) L. Liu, B. Lukose, P. Jaque, B. Ensing, Green Energy Environ. 2019, 4, 20-28.

[10] K. Chernichenko, A. Madarasz, I. Papai, M. Nieger, M. Leskela, T. Repo, Nature Chem. 2013, 5, 718-723.

[11] L. Greb, P. Ona-Burgos, B. Schirmer, S. Grimme, D. W. Stephan, J. Paradies, Angew. Chem. Int. Ed. 2012, 51, 10164-10168.

[12] T. Mahdi, D. W. Stephan, J. Am. Chem. Soc. 2014, 136, 15809-15812.

[13] H. Wang, R. Frohlich, G. Kehr, G. Erker, Chem. Commun. 2008, 5966-5968.

[14] T. Mahdi, Z. M. Heiden, S. Grimme, D. W. Stephan, J. Am. Chem. Soc. 2012, 134, 4088-4091.

[15] P. A. Chase, G. C. Welch, T. Jurca, D. W. Stephan, Angew. Chem. Int. Ed. 2007, 46, 8050-8053.

[16] P. Spies, S. Schwendemann, S. Lange, G. Kehr, R. Frohlich, G. Erker, Angew. Chem. Int. Ed. 2008, 47, 7543-7546.

[17] N. A. Sitte, M. Bursch, S. Grimme, J. Paradies, J. Am. Chem. Soc. 2019, 141, 159-162.

[18] I. Khan, M. Manzotti, G. J. Tizzard, S. J. Coles, R. L. Melen, L. C. Morrill, ACS Catal. 2017, 7, 7748-7752.

[19] J. S. Sapsford, D. Csokas, R. C. Turnell-Ritson, L. A. Parkin, A. D. Crawford, I. Papai, A. E. Ashley, ACS Catal. 2021, 11, 9143-9150.

[20] V. Sumerin, F. Schulz, M. Nieger, M. Leskela, T. Repo, B. Rieger, Angew. Chem. Int. Ed. 2008, 47, 6001-6003.

[21] A. E. Ashley, A. L. Thompson, D. O'Hare, Angew. Chem. Int. Ed. 2009, 48, 9839-9843.

[22] I. B. Sivaev, V. I. Bregadze, Coord. Chem. Rev. 2014, 270, 75-88.

[23] D. J. Parks, R. E. V. H. Spence, W. E. Piers, Angewandte Chemie-International Edition in English 1995, 34, 809-811.

[24] Z. M. Heiden, A. P. Lathem, Organometallics 2015, 34, 1818-1827.

[25] a) P. Sabatier, Ber. Dtsch. Chem. Ges. 1911, 44, 1984-2001; b) M. D. Wodrich, B. Sawatlon, M. Busch, C. Corminboeuf, ChemCatChem 2018, 10, 1586-1591.

[26] a) I. Kaljurand, A. Kutt, L. Soovali, T. Rodima, V. Maemets, I. Leito, I. A. Koppel, J. Org. Chem. 2005, 70, 1019-1028; b) A. M. Kelly-Rowley, V. M. Lynch, E. V. Anslyn, J. Am. Chem. Soc. 2002, 117, 3438-3447; c) pKa value of TMP taken from the supplier Merck, https://www.sigmaaldrich.com/chemistry/chemical-synthesis/learning-

center/chemfiles/chemfile-2001-2003/vol-3-no-1/traditional-strong-and-hindered-bases.html,

Accessed 07/01/2022

[27] a) S. J. Geier, D. W. Stephan, J. Am. Chem. Soc. 2009, 131, 3476-3477; b) C. Jiang, O. Blacque, T. Fox, H. Berke, Dalton Trans. 2011, 40, 1091-1097.

[28] S. Moebs-Sanchez, N. Saffon, G. Bouhadir, L. Maron, D. Bourissou, Dalton Trans. 2010, 39, 4417-4420.

[29] a) S. Grimme, H. Kruse, L. Goerigk, G. Erker, Angew. Chem. Int. Ed. 2010, 49, 14021405; b) T. A. Rokob, I. Pápai, in Frustrated Lewis Pairs I, Vol. 332 (Eds.: G. Erker, D. W. 
Stephan), Springer Berlin Heidelberg, Berlin, Heidelberg, 2013, pp. 157-211; c) G. Skara, F. De Vleeschouwer, P. Geerlings, F. De Proft, B. Pinter, Sci Rep. 2017, 7, 16024.

[30] L. Greb, C. G. Daniliuc, K. Bergander, J. Paradies, Angew. Chem. Int. Ed. 2013, 52, 5876-5879.

[31] a) J. Bures, Angew. Chem. Int. Ed. 2016, 55, 2028-2031; b) J. Bures, Angew. Chem. Int. Ed. 2016, 55, 16084-16087. 